\title{
The Dynamic Linkage among the Size, Growth and Profitability of Listed Companies in the ASEAN-4 Countries
}

\author{
Phassawan Suntraruk \\ Business Administration Division, Mahidol University International College \\ phassawan.sun@mahidol.ac.th \\ Kanix Bukkavesa \\ Business Administration Division, Mahidol University International College \\ kanix.buk@mahidol.ac.th \\ Nat Kulvanich \\ Department of Statistics, Faculty of Commerce and Accountancy, \\ Chulalongkorn University \\ nat@cbs.chula.ac.th
}

\begin{abstract}
The purpose of this paper is to examine the dynamic relationship among the size, growth, and profitability of listed companies. The study sample comprised listed companies in the ASEAN-4 countries-Malaysia, the Philippines, Singapore, and Thailand-over the period 1972-2014. The K-medoids algorithm was employed in a cluster analysis, and the generalized method of moments (GMM) was applied to examine the dynamic relationship. The empirical results reveal that smaller companies tend to have higher growth than larger companies. Moreover, the results indicate that persistence of growth and persistence of profitability do not exist. There is also evidence that profitability affects companies' growth, but companies' growth does not affect profitability.
\end{abstract}

Keywords: ASEAN, GMM, Growth, Profitability, Size

\section{INTRODUCTION}

Since the ASEAN community was established in 2015, the economic growth of the ASEAN countries has increased significantly. The free flow of investment has encouraged foreign direct investment in all the ASEAN countries, which should further increase the competition among companies in terms of products sold, services rendered, investment opportunities, and financial resources. The increasing competition will 
therefore alter the economic structure of the ASEAN countries and increase the added value of their economies. As a result, understanding the uniqueness of the companies in ASEAN countries in terms of growth and profitability can help potential investors reduce investment and financial risks.

Recently, a wide range of investigations have produced conflicting findings regarding the relationships among size, growth, and profitability. First, empirical studies have left unanswered the question of the bidirectional relationship between companies' growth and profitability. Basically, growth and profitability are variables that are important to business survival and success. Profits are significant resources used to finance business expansion; therefore, a company's profitability is likely a significant determinant of its growth (Goddard et al., 2004; Nakano \& Kim, 2011; Coad, 2007). Nonetheless, a company's growth provides chances for substantial profitability in the future. Growth itself is then considered a determinant of profitability (Coad, 2007; Geroski et al., 1997; Nakano \& Kim, 2011). Accordingly, both growth and profitability are connected to business success. Hence, the purpose of this study is to investigate the relationship between companies' growth and profitability.

Moreover, in terms of the relationship between a company's growth and size, many researchers have tested Gibrat's Law, which posits that a company's growth and size are independent (Gibrat, 1931). However, the findings of these studies have been inconsistent worldwide. Many researchers have found support for Gibrat's Law (e.g., Geroski et al.,2003; Liñares-Zegarra, \& Wilson, 2018), while others have rejected Gibrat's Law by proving that a company's growth is significantly related to its size (e.g., Evans, 1987; Dunne \& Hughes, 1994; Audretsch et al. 1999; Shehzad et al., 2013; Gao et al., 2016). Therefore, this study also aims to examine the validity of Gibrat's Law to determine whether a company's growth affects its size.

In addition to the effect of a company's size, this study investigates the persistence of profitability framework, where past profit directly affects current profit. As profits are potential resources for running a business, a company is unlikely to survive for a significant period without generating any profits. Therefore, a company's profitability in the past, present and future indicates its performance and sustainability.

For these purposes, this study sample comprised listed companies in four ASEAN countries: Malaysia, the Philippines, Singapore, and Thailand (the ASEAN-4 countries). Although the ASEAN community consists of 10 countries, this study emphasized only these four because they are in the same stage of economic growth, and they have developed active stock markets relatively recently.

The rest of the paper is organized as follows. The next section explains the related literature and the testable hypothesis. The third section describes the data and 
methodology. The fourth section presents the empirical results and the discussion. The final section concludes.

\section{LITERATURE REVIEW}

The relationships among size, growth and profitability have been investigated extensively since the 1930s. Gibrat (1931) initially introduced Gibrat's Law, in which he revealed that the growth rate of a company is independent of its size. Thus, he predicted that companies' growth rates are not affected by their size. Gibrat's Law was later reinforced by Geroski et al. (2003), who examined the growth-size relationship based on large time spans of over 30 years. The authors reported that Gibrat's Law tended to hold for large UK companies. Recently, Liñares-Zegarra, and Wilson (2018) revealed an insignificant relationship between companies' growth and size for large microfinance institutions in 120 countries, supporting Gibrat's Law.

However, Gibrat's Law contrasts with many empirical studies. Evans (1987) studied the relationship between companies' growth and size using manufacturing companies operating between 1976 and 1982 as the sample. He found that companies' growth significantly declined when their size increased. In addition, Hart and Oulton (1996) and Dunne and Hughes (1994) investigated the growth of UK companies found that the growth rate of smaller companies was greater than that of larger firms. This finding of a negative relationship was consistent with that of Shehzad et al. (2013), who examined the relationship between growth and the size of banks across 148 countries, including OECD countries. The authors reported that although the growth of banks was not persistent, the growth rate of smaller banks in OECD countries was higher than that of larger banks. Moreover, Oliveira and Fortunato (2006) argued against Gibrat's Law. They found an inverse growth-size relationship for Portuguese manufacturing companies, thus supporting the finding of Goddard et al. (2002) based on Japanese manufacturing companies over the period from 1980-1996. In addition, Distante et al. (2018) disagreed with Gibrat's Law. By using quantile regression analysis, they revealed that smaller firms grow faster than larger ones, supporting evidence found by both Audretsch et al. (1999) in the case of Italian manufacturing companies and Gao et al. (2016) in the case of online stores in a Chinese online marketplace named Taobao.com. As there is conflicting evidence regarding the growth-size relationship of Gibrat's Law, the first testable hypothesis is as follows:

H1: A company's size affects its growth.

In addition to the growth-size relationship, the linkage between companies' growth and profitability has been explored continuously. Companies generating profits have more opportunities to expand and grow their operations. They reinvest their partial 
profits into new business environments or even expand their current operations in order to generate greater profits from a larger business. Therefore, the relationship between growth and profitability tends to be positive when the business environment has the potential for investment and growth. If not, then the relationship is relatively weak.

As profits are an effective source of business financing for future expansion, many empirical studies have examined the growth-profit relationship. Goddard et al. (2004) found consistent support for a growth-profit relationship. Their results showed that current profits affected predictions of future growth for European banks over the period from 1992-1998. The authors also reported that larger banks are more likely to have higher future growth performance. Moreover, using Japanese manufacturing companies over the period from 1987-2007 as the sample, Nakano and Kim (2011) examined the association between companies' growth and profitability and found that current profits are a significant determinant of future growth. Contrary to the above findings indicating a positive relationship, Lee (2014) reported that for South Korean companies, profits affect growth inversely. Adding more controversy to the existing literature, Coad (2007) revealed an insignificant association between companies' growth and profitability for French manufacturing companies, which was consistent with Gupta (1969), who examined U.S. manufacturing companies. As the existing results leave us with a contradiction that must be resolved, the following testable hypothesis is proposed:

H2: Profitability affects a company's growth.

Although profitability can help stimulate growth, growth itself helps boost profitability. Companies with high growth rates are more likely to benefit from economies of scale. Their dynamic increasing returns generated from their experience gained through rapid growth are likely to reduce their production costs and further improve productivity, ultimately allowing them to enhance their profitability. Therefore, in addition to the effect of profits on growth, the effect of growth on profits has been investigated dynamically. Nakano and Kim (2011) showed that growth is important when predicting future profits. Indeed, Geroski et al. (1997) found that for large UK companies established during the period from 1976-1982, their growth rates were positively related to changes in their forecasted profitability over the long run. Moreover, Coad (2007) reported a positive association between past growth and future profit rates. This empirical result accorded with the findings of Coad (2007, 2010), Coad et al. (2011), Cowling (2004), and Lee (2014). According to the recently reported findings, the following hypothesis is tested:

H3: A company's growth affects its future profitability. 
Despite the fact that attaining a sufficiently high degree of profit is crucial to sustaining long-run business growth, persistence of profitability is also important because it depends on the market and the competitive environment. According to the persistence of profitability framework proposed by Mueller (1977), free entry to and existence in the market sufficiently and rapidly decreases the attainment of abnormal profits. As a result, there is a tendency for profit rates to converge towards the same average values or norms over time. Nonetheless, companies with sustainable competitive advantages, for example, superior processes, specific knowledge, or effective technology management, are able to create a substantial barrier to entry that allows them to continue to earn abnormal profits persistently over time. The persistence of profitability framework has also been examined by several researchers. Nunes et al. (2009) investigated the factors that affect profitability in the Portuguese service industry and found that profitability is persistent over time. Shehzad et al. (2013) also showed the persistence of profitability in the case of banks. Finally, Nunes and Serrasqueiro (2015) studied the factors that impact the profitability of knowledge-intensive business services in Portugal. They discovered that profitability in such firms is persistent over time. The following testable hypothesis is proposed:

H4: There exists the persistence of profitability.

\section{DATA AND METHODOLOGY}

\section{Data and Sample Selection}

This study focuses on the ASEAN countries, as the establishment of the ASEAN community in 2015 boosted the foreign direct investment and economic growth of each country. By the end of 2014, out of ten ASEAN countries, eight had stock exchanges. Therefore, to select the sample for this study, the K-medoids algorithm suggested by Struyf et al. (1997) was employed in a cluster analysis. The movement characteristics of the value of GDP per capita for the period between 1994 and 2014 were then used in the clustering algorithm. With this technique, it is expected that the countries analyzed in this study have some commonalities between companies' profits and GDP per capita and most importantly, that they follow a similar growth trend over the long term.

According to the results derived from the K-medoids clustering technique, eight ASEAN countries can be classified into two groups, each of which has similar movement characteristics for GDP per capita. The first group includes Malaysia, the Philippines, Singapore, and Thailand, which all have high average GDP per capita but low average year-to-year GDP growth. The second group consists of Cambodia, Indonesia, Laos, and Vietnam. These countries have low average GDP per capita but high average year-to-year GDP growth. 
Based on the results of the cluster analysis, the first group with high average GDP per capita was employed in this study. Because these high GDP countries normally show flat or stable growth trends, they are mature and thus appropriate for studying the two-way relationship between companies' growth and profitability. By contrast, the second group was excluded because the company structure and industry structure within these countries are in their infancy due to low average GDP per capita with high average year-to-year GDP growth, unlike the first group, in which most of the industries are either in or close to their maturity phase. In addition, the financial data for companies in the countries in the second group were materially limited and incomplete compared with those in the first group.

As a result, the sample in this study consists of companies listed on the stock exchanges of Malaysia, the Philippines, Singapore, and Thailand since the start of each exchange until the year 2014. For Malaysia, the sample period is between 1972 and 2014. For the Philippines, the sample period is between 1985 and 2014. For Singapore, it is between 1972 and 2014, and for Thailand, it is between 1987 and 2014. Malaysia and Singapore each have 3 exchanges. Thailand has 2 exchanges, whereas the Philippines has 1 exchange. Our sample therefore includes all companies with available data and listed on all exchanges in these four countries. Those companies with incomplete and abnormal data were excluded from the sample.

\section{Dynamic Regression Models}

To test the hypotheses of this study, the dynamic panel growth and profit models presented below were used for the estimation, following Goddard et al. (2004) and Nakano and Kim (2011). The use of dynamic panel estimators allows us to examine whether companies' growth and profitability in the current period are related to their growth and profitability in the previous period.

$$
\begin{aligned}
\Delta \text { Size }_{i, t}= & \gamma_{i}+\alpha_{1} \text { Size }_{i, t-1}+\alpha_{2} \Delta \text { Size }_{i, t-1}+\alpha_{3} B E P_{i, t-1}+\alpha_{4} C A P_{i, t} \\
& +\alpha_{5} \text { FIN }_{i, t}+\alpha_{6} L I Q_{i, t}+\varepsilon_{1, i, t} \\
B E P_{i, t}= & \delta_{i}+\beta_{1} B E P_{i, t-1}+\beta_{2} \Delta \text { Size }_{i, t-1}+\beta_{3} C A P_{i, t} \\
& +\beta_{4} \text { FIN }_{i, t}+\beta_{5} L_{I} Q_{i, t}+\varepsilon_{2, i, t}
\end{aligned}
$$

Model 1 presents the growth-profit relationship model, and Model 2 presents the profit-growth relationship model. With respect to both models, Size $e_{i, t}$ is the logarithmic assets of company $i$ in year $t$, and $\Delta S_{i z e_{i, t}}$ is the difference between Size $e_{i, t}$ and Size $_{i, t-1}$, presenting the logarithmic asset growth of company $i$ in each year. $B E P_{i, t}$ is the basic earning power or profits of company $i$ in year $t$, calculated as earnings before interest and taxes divided by total assets. The basic earning power was used in this study in order to analyze the true potential of companies excluding their leverage. 
The control variables consist of $C A P_{i, t}$, which is the capital structure ratio of company $i$ in year $t$, computed as total liabilities divided by total equity. The next control variable, $F I N_{i, t}$, represents the financial leverage ratio of company $i$ in year $t$, which is defined as total debt to total equity. Although these two variables are similar in liabilities and debt measurement, they have one substantial difference. Generally, $C A P_{i, t}$ includes all types of liabilities, including both non-interest-bearing debt and interest-bearing debt. On the other hand, FIN $_{i, t}$ includes only interest-bearing debt. Hence, these two variables can help differentiate relatively weak, high-risk companies from stronger ones. For example, a company with a higher financial leverage ratio $\left(F I N_{i, t}\right)$ is believed to have greater financial risk. However, a company with a high capital structure ratio $\left(C A P_{i, t}\right)$ with non-interest-bearing debt, e.g., accounts payable, is interpreted as potentially having higher competitiveness in the industry because of its effective working capital management and negotiation power with suppliers.

The last control variable, $L I Q_{i, t}$, is the liquidity ratio of company $i$ in year $t$, defined as total current assets to total current liabilities. Finally, $\varepsilon_{1, i, t}$ and $\varepsilon_{2, i, t}$ are random error terms. All data employed are fundamental year-end company data and were obtained from the companies' financial statements derived from the Worldscope database through Reuters.

\section{Statistical Methods}

To estimate the above dynamic regression models, Models 1 and 2, the generalized method of moments (GMM) was employed. Since our dataset is a collection of both panel and time-series cases with potential endogeneity issues, a typical time-series model might not be suitable in this scenario. A GMM estimation is more appropriate as it is a dynamic panel data model that controls for fixed effects and incidental trends. Moreover, GMM estimation effectively handles endogeneity between the dependent variables and instruments with lagged-one dependent variables (Arellano \& Bond, 1991).

Moreover, the data set in this study consists of companies of different sizes (smallsized, medium-sized, and large-sized companies), and these companies operate in different industrial sectors. This could cause different correlation structures across the companies. Therefore, to allow for heterogeneity across companies, the white period weighting matrix suggested by Arellano and Bond (1991) was implemented to allow the correlation structures to vary across the cross-sections.

In addition, to understand the uniqueness of the companies in each sub-group, the sub-sample regressions were employed for both models. For each sample country, all companies were classified based on the values of their growth and profits. Thus, the companies in a group operate in every industry and have the same or similar ranges for 
their growth and profits. This group classification allows the dynamics and evolution of each characteristic to be more clearly understood.

There are several statistical techniques that can be used to create groups of observations with roughly the same number of observations in each group. However, quantiles of data were used to form the categories in this study, as they intuitively appeal to values of growth and profits and allow for analysis in terms of low-, medium- and high-value groups. To group the observations, the growth and profits of companies were first ranked separately in each country, and then the quantiles were calculated. Approximately $25 \%$ of the companies are considered "small-sized companies," in which the values of growth and profits are lower than the first quantile. Approximately $50 \%$ of the companies are considered "medium-sized companies," in which the values of growth and profits lie between first quantile and third quantile. Finally, the "largesized" companies include $25 \%$ of the companies, in which the values of growth and profits are higher than the third quantile.

The primary reason that we segregate groups of observations into 3 quantiles instead of using sectors or industries is that each country classifies its own listed companies in an industry, resulting in differences in industry names and classifications. Hence, classifying companies based on industry names would not represent the true nature of the companies. Moreover, the insufficient data for some industries in some countries do not allow us to conduct the sub-industry analysis and run the GMM regression accordingly. As a result, running the statistical analysis by industry grouping is unable to explain any dissolution to a significant degree and to draw any strong conclusions.

\section{EMPIRICAL RESULTS AND DISCUSSION}

\section{Descriptive Statistics}

Table 1 provides the descriptive statistics of the dependent and independent variables examined in this study. The table shows that the average size of companies measured by their assets is approximately the same for all ASEAN-4 countries. However, in terms of profitability, capital structure ratio, financial leverage ratio, and liquidity ratio, the results are relatively volatile, as the standard deviations are greater than the average for each variable. 
Table 1. Descriptive statistics

Panel A: Malaysia and Philippines

\begin{tabular}{|c|c|c|c|c|c|c|c|c|}
\hline \multirow{2}{*}{ VAR. } & \multicolumn{4}{|c|}{ Malaysia $($ Observations $=16,000)$} & \multicolumn{4}{|c|}{ Philippines (Observations $=4,618$ ) } \\
\hline & Mean & Max & Min & SD & Mean & Max & Min & SD \\
\hline SIZE & 5.458 & 8.688 & 0.778 & 0.673 & 6.513 & 9.122 & 1.176 & 1.015 \\
\hline BEP & 0.029 & 75.292 & -64.307 & 1.018 & -0.712 & 2.968 & -2271.95 & 34.701 \\
\hline$C A P$ & 1.548 & 5288.970 & -678.15 & 46.104 & 0.292 & 2040.96 & -2167.66 & 85.375 \\
\hline FIN & 1.053 & 4913.735 & -476.51 & 41.271 & 1.783 & 839.677 & -95.265 & 27.164 \\
\hline$L I Q$ & 2.915 & 282.419 & 0.00001 & 7.626 & 12.746 & 3528.28 & 0.0003 & 87.301 \\
\hline \multicolumn{9}{|c|}{ Panel B: Singapore and Thailand } \\
\hline \multirow{2}{*}{ VAR. } & \multicolumn{4}{|c|}{ Singapore $($ Observations $=13,794)$} & \multicolumn{4}{|c|}{ Thailand (Observations $=8,578)$} \\
\hline & Mean & Max & Min & SD & Mean & Max & Min & SD \\
\hline SIZE & 5.331 & 10.390 & 0.778 & 0.811 & 6.425 & 9.252 & 3.220 & 0.662 \\
\hline BEP & 0.106 & 1412.964 & -339.28 & 12.440 & 0.319 & 2099.987 & -10.383 & 22.677 \\
\hline CAP & 1.405 & 1994.700 & -517.14 & 20.312 & 4.328 & 10059.73 & -359.521 & 137.64 \\
\hline FIN & 0.561 & 187.803 & -388.69 & 7.327 & 2.967 & 9884.523 & -271.648 & 110.99 \\
\hline$L I Q$ & 2.491 & 179.351 & 0.0001 & 4.540 & 2.305 & 388.680 & 0.0001 & 7.450 \\
\hline
\end{tabular}

\section{Regression Results}

Table 2 presents the results of the dynamic relationship between growth and profitability. The results suggest that for all sample countries, companies' growth $\left(\triangle S I Z E_{t}\right)$ is significantly and negatively related to the companies' size $\left(S I Z E_{t}\right)$, supporting hypothesis H1. Smaller companies are likely to have higher growth than larger companies. As they are more nimble than larger companies, which makes it easier for them to adapt to change, they tend to grow faster than larger ones. This finding is therefore consistent with Evans (1987), Dunne and Hughes (1994), Audretsch et al. (1999), Goddard et al. (2002), Oliveira and Fortunato (2006), Shehzad et al. (2013), and Gao et al. (2016), as well as Distante et al. (2018); however our finding contradicts Gibrat's Law that a company's growth is independent of its size.

Moreover, the results in Table 2 show that there is a negative relationship between past growth $\left(\triangle S I Z E_{t-1}\right)$ and current growth $\left(\triangle S I Z E_{t}\right)$ in the cases of Malaysia and Thailand and an insignificant relationship in the cases of the Philippines and Singapore. Such findings, therefore, confirm that persistence of growth does not exist. 
Table 2. Dynamic regression analysis results: Growth-profit relationship Dependent Variable: Growth $\left(\Delta \mathrm{Size}_{t}\right)$

\begin{tabular}{|c|l|l|l|l|}
\hline Independent Variables & Malaysia & Philippines & Singapore & Thailand \\
\hline Size $_{(t-1)}$ & $-0.606^{* * *}$ & $-0.655^{* * *}$ & $-0.615^{* * *}$ & $-0.530^{* * *}$ \\
\hline \multirow{2}{*}{$\Delta$ Size $_{(t-1)}$} & -19.786 & -10.235 & -13.860 & -17.772 \\
\hline \multirow{2}{*}{$\boldsymbol{E P}_{(t-1)}$} & $-0.053^{* * *}$ & 0.007 & -0.030 & $-0.105^{* * *}$ \\
& -3.981 & 0.187 & -0.838 & -3.726 \\
\hline \multirow{2}{*}{$\boldsymbol{C A P}_{(t)}$} & $0.005^{* *}$ & -0.0004 & $0.0008^{* *}$ & $0.0004^{* * *}$ \\
& 2.051 & -1.583 & 2.007 & 8.565 \\
\hline \multirow{2}{*}{$\boldsymbol{F I N}_{(t)}$} & $0.003^{*}$ & $-0.0007^{* * *}$ & -0.0002 & 0.0000 \\
\hline \multirow{2}{*}{$\boldsymbol{I I}_{(t)}$} & 1.737 & -6.535 & -0.353 & 0.049 \\
\hline & $-0.004^{*}$ & $0.003^{* * *}$ & 0.0000 & 0.0000 \\
& -1.730 & 7.542 & 0.012 & 1.140 \\
\hline & 0.0003 & 0.0000 & -0.0004 & -0.0006 \\
\hline
\end{tabular}

Notes: The number in the first line represents the regression coefficient, while the number in the second line is its related p-value. *, **, and *** denote significance at the $10 \%, 5 \%$, and $1 \%$ levels, respectively.

When considering each sub-sample, Table 3 supports that there is no persistence of growth based on the negative relationship between companies' growth $\left(\triangle S I Z E_{t}\right)$ and companies' size $\left(S I Z E_{t}\right)$ for all countries and all sub-groups. The reason for this negative relationship is that in a country with limited potential for growth, once there is growth in certain years, it is normal for the economy to pause as the rest of the economy catches up with that growth. This situation is unlike larger countries such as the U.S., where once growth momentum starts, it normally continues for a couple of years.

In terms of profitability, the results in Table 2 and Table 3 reveal that there is a significant and negative relationship between companies' growth $\left(\triangle S I Z E_{t}\right)$ and past profits $\left(B E P_{t-1}\right)$. Thus, hypothesis $\mathrm{H} 2$ is supported. The finding of a negative relationship implies that past profit is a determinant of companies' growth such that the greater the profits, the higher the growth for companies listed in Malaysia, Singapore and Thailand, supporting the results of Goddard et al. (2004) and Nakano and Kim (2011). In general, companies with high profit margins have greater competitive advantage in terms of cost advantages through economies of scale (Gupta, 1981), high bargaining power, and better access to distribution channels (Markman \& Gartner, 2002). All these factors can further improve companies' profitability and allow such high-profit companies to maintain their growth momentum. Moreover, an increase in profit margins, which provides an internal source of funds, leads to increases in investment and thus business expansion (Myers \& Majluf, 1984). As a result, companies' earlier profit margins transform into a future higher growth rate. 
Table 3. Dynamic regression analysis of sub-sample data: Growth-profit relationship Dependent Variable: Growth (USizet)

\begin{tabular}{|c|c|c|c|c|c|c|}
\hline \multicolumn{7}{|c|}{ Panel A: Malaysia and Philippines } \\
\hline \multirow{2}{*}{$\begin{array}{c}\text { Independent } \\
\text { Variables }\end{array}$} & \multicolumn{3}{|c|}{ Malaysia } & \multicolumn{3}{|c|}{ Philippines } \\
\hline & Large & Medium & Small & Large & Medium & Small \\
\hline Size $_{(t-1)}$ & $\begin{array}{c}-0.332^{* * *} \\
-10.227\end{array}$ & $\begin{array}{c}-0.610^{* * *} \\
-16.294\end{array}$ & $\begin{array}{l}-0.501^{* * *} \\
-4.293\end{array}$ & $\begin{array}{l}-0.147^{* * *} \\
-5.325\end{array}$ & $\begin{array}{l}-0.635^{* * *} \\
-7.973\end{array}$ & $\begin{array}{l}-0.566^{* * *} \\
-5.237\end{array}$ \\
\hline$\Delta$ Size $_{(t-1)}$ & $\begin{array}{l}-0.108^{* * *} \\
-4.413\end{array}$ & $\begin{array}{l}-0.117^{* *} \\
-1.967\end{array}$ & $\begin{array}{l}0.019 \\
0.656\end{array}$ & $\begin{array}{l}-0.025 \\
-0.842\end{array}$ & $\begin{array}{l}-0.063 \\
-0.815\end{array}$ & $\begin{array}{l}-0.012 \\
-0.827\end{array}$ \\
\hline $\boldsymbol{B E P}(t-1)$ & $\begin{array}{l}0.103^{* * *} \\
2.898\end{array}$ & $\begin{array}{l}0.027^{* *} \\
2.195\end{array}$ & $\begin{array}{l}0.005 \\
0.788\end{array}$ & $\begin{array}{l}0.057 \\
1.389\end{array}$ & $\begin{array}{l}0.027 \\
0.450\end{array}$ & $\begin{array}{l}-0.0002 \\
-1.621\end{array}$ \\
\hline $\boldsymbol{C A P}(t)$ & $\begin{array}{l}0.014^{* *} \\
2.558\end{array}$ & $\begin{array}{l}0.005^{* * *} \\
3.187\end{array}$ & $\begin{array}{l}0.001^{\text {** }} \\
2.023\end{array}$ & $\begin{array}{l}-0.001^{* *} \\
-2.534\end{array}$ & $\begin{array}{l}-0.0005^{* * *} \\
-6.581\end{array}$ & $\begin{array}{l}-0.001 \\
-1.096\end{array}$ \\
\hline $\boldsymbol{F I N}_{(t)}$ & $\begin{array}{l}-0.018^{* *} \\
-2.335\end{array}$ & $\begin{array}{l}-0.006^{* * *} \\
-3.170\end{array}$ & $\begin{array}{l}-0.001^{* *} \\
-1.986\end{array}$ & $\begin{array}{l}0.002^{* * *} \\
2.645\end{array}$ & $\begin{array}{l}0.003^{* * *} \\
9.541\end{array}$ & $\begin{array}{l}0.0001^{* *} \\
2.032\end{array}$ \\
\hline$L I Q_{(t)}$ & $\begin{array}{l}-0.0002 \\
-0.398\end{array}$ & $\begin{array}{l}0.0001 \\
0.091\end{array}$ & $\begin{array}{l}0.003 \\
1.611\end{array}$ & $\begin{array}{l}-0.0004 \\
-1.517\end{array}$ & $\begin{array}{l}0.001 \\
1.194\end{array}$ & $\begin{array}{l}0.0004 \\
1.516\end{array}$ \\
\hline
\end{tabular}

\section{Panel B: Singapore and Thailand}

\begin{tabular}{|c|l|l|l|l|l|l|}
\hline \multirow{2}{*}{$\begin{array}{c}\text { Independent } \\
\text { Variables }\end{array}$} & \multicolumn{3}{|c|}{ Singapore } & \multicolumn{3}{c|}{ Thailand } \\
\cline { 2 - 7 } & Large & Medium & Small & Large & Medium & Small \\
\hline \multirow{2}{*}{ Size $_{(t-1)}$} & $-0.241^{* * *}$ & $-0.686^{* * *}$ & $-0.673^{* * *}$ & $-0.245^{* * *}$ & $-0.585^{* * *}$ & $-0.619^{* * * *}$ \\
& -5.028 & -13.707 & -9.947 & -8.287 & -16.794 & -15.343 \\
\hline \multirow{2}{*}{$\Delta$ Size $_{(t-1)}$} & $-0.205^{* * *}$ & $-0.127^{* *}$ & 0.074 & $-0.078^{* *}$ & $-0.017^{*}$ & -0.029 \\
& -2.738 & -2.047 & 1.485 & -2.012 & -1.997 & -0.375 \\
\hline \multirow{2}{*}{$\boldsymbol{B E P}_{(t-1)}$} & $0.008^{* * *}$ & $0.001^{* * *}$ & $0.010^{* * *}$ & $0.104^{* *}$ & $0.024^{* *}$ & $0.0003^{* * *}$ \\
& 9.735 & 9.131 & 12.779 & 2.123 & 2.428 & 9.795 \\
\hline \multirow{2}{*}{$\boldsymbol{C A P}_{(t)}$} & 0.010 & -0.001 & 0.001 & 0.0000 & 0.0001 & -0.0009 \\
& 1.247 & -0.679 & 1.616 & 0.863 & 0.305 & -1.363 \\
\hline \multirow{2}{*}{$\boldsymbol{F I N}_{(t)}$} & -0.015 & 0.002 & -0.001 & -0.0000 & -0.0001 & 0.001 \\
& -0.715 & 0.727 & -1.233 & -0.494 & -0.280 & 1.493 \\
\hline \multirow{2}{*}{$\boldsymbol{L I Q}_{(t)}$} & -0.005 & -0.001 & -0.003 & -0.005 & -0.0006 & -0.001 \\
& -1.104 & -0.934 & -1.512 & -1.636 & -0.981 & -0.864 \\
\hline
\end{tabular}

Notes: The number in the first line represents the regression coefficient, while the number in the second line is its related p-value. $*, * *$, and $* * *$ denote significance at the $10 \%$, $5 \%$, and $1 \%$ levels, respectively.

For the capital structure control variable $\left(C A P_{t}\right)$, Tables 2 and 3 present that the relationship is significantly positive for companies in Malaysia, regardless of size. This result indicates that companies in Malaysia with higher ratios of total liabilities to total equity have higher bargaining power than other companies. These companies are able to borrow from suppliers at a lower cost, resulting in lower leverage and consequently 
leading to higher growth. This empirical finding supports the evidence showing a negative relationship between companies' growth $\left(\triangle S I Z E_{t}\right)$ and leverage $\left(F I N_{t}\right)$, as companies with lower leverage tend to grow their assets more.

In contrast to companies in Malaysia, in the case of the Philippines, Tables 2 and 3 show a negative relationship between companies' growth $\left(\triangle S I Z E_{t}\right)$ and the capital structure ratio $\left(C A P_{t}\right)$. This negative relationship reveals that companies with lower ratios of total liabilities to total equity have higher leverage. Although high-leverage companies are risky, the evidence shows that these companies grow faster than others. This result also accords with the positive relationship found between companies' growth $\left(\triangle S I Z E_{t}\right)$ and leverage $\left(F I N_{t}\right)$ in the Philippines. Finally, in terms of liquidity $\left(L I Q_{t}\right)$, no significant growth-liquidity relationship is found for all sample countries and all sub-groups.

Table 4. Dynamic regression analysis results: Profit-growth relationship

\begin{tabular}{|c|c|c|c|c|}
\hline \multicolumn{5}{|c|}{ Dependent Variable: Profit $\left(\boldsymbol{B E P}_{t}\right)$} \\
\hline \multirow{2}{*}{ Independent Variables } & Malaysia & Philippines & Singapore & Thailand \\
\hline \multirow{2}{*}{$\boldsymbol{E P P}_{(t-1)}$} & 0.066 & $-0.008^{*}$ & $-0.190^{* * *}$ & $-0.070^{* * *}$ \\
\hline \multirow{2}{*}{ Size $_{(t-1)}$} & 0.604 & -1.926 & -8.440 & -736.522 \\
\hline \multirow{2}{*}{$\boldsymbol{C A P}_{(t)}$} & 0.0000 & 0.0000 & 0.0000 & -0.0000 \\
& 0.844 & 1.079 & 0.718 & -0.943 \\
\hline \multirow{2}{*}{$\boldsymbol{F I N}_{(t)}$} & 0.004 & 0.001 & -0.114 & -0.001 \\
\multirow{2}{*}{$\boldsymbol{L I Q}_{(t)}$} & 1.336 & 0.460 & -1.018 & -0.714 \\
\hline & -0.005 & -0.011 & -0.204 & 0.001 \\
& -1.709 & -0.762 & -1.012 & 0.722 \\
\hline & $0.002^{* *}$ & 0.001 & 0.008 & 0.031 \\
& 2.386 & 0.982 & 1.245 & 0.844 \\
\hline
\end{tabular}

Notes: The number in the first line represents the regression coefficient, while the number in the second line is its related p-value. *,**, and *** denote significance at the $10 \%$, $5 \%$, and $1 \%$ levels, respectively.

Table 4 below presents the regression results of the profit-growth model and shows that past profits $\left(B E P_{t-1}\right)$ negatively affect current profits $\left(B E P_{t}\right)$ for listed companies in the Philippines, Singapore and Thailand, whereas for Malaysia, the relationship is not statistically significant. These empirical results imply that there is no persistence of profitability; hence hypothesis $\mathrm{H} 4$ is not supported. Indeed, the negative relationship indicates that higher profits in the prior year results in lower profits in the current year and vice versa. Nonetheless, this finding is inconsistent with the results found by Nunes et al. (2009), Shehzad et al. (2013) and Nunes and Serrasqueiro (2015). Concerning the relationship between profitability $\left(B E P_{t}\right)$ and growth $\left(\triangle S I Z E_{t-1}\right)$, the results in Table 4 
for all sample countries indicate an insignificant relationship, rejecting hypothesis $\mathrm{H} 3$ that a company's growth does not affect its future profitability.

In addition, regarding the relationship between profitability $\left(B E P_{t}\right)$ and growth $\left(\triangle S I Z E_{t-1}\right)$, Table 5 indicates that although the coefficients are relatively minimal, a negative and significant relationship is observed for large and medium-sized companies in the Philippines, meaning that higher asset growth results in lower profits and vice versa. Thus, these companies could buy a set of assets for the purpose of greater diversification, resulting in high growth in asset size. When the companies recognize depreciation expenses, but their revenues have not grown enough to compensate for such expenses, it causes lower profits in the next period. As a result, higher asset growth is more likely to constrain profits.

Moreover, the relationship between profitability $\left(B E P_{t}\right)$ and the capital structure ratio $\left(C A P_{t}\right)$ is statistically insignificant for all sample countries, as shown in Table 4. Nonetheless, when considering each segment, Table 5 indicates a negative and significant relationship between profitability $\left(B E P_{t}\right)$ and the capital structure ratio $\left(C A P_{t}\right)$ in the case of large-sized companies in the Philippines and small-sized companies in Singapore, which is inconsistent with Goddard et al. (2005). This result means that a high level of liabilities tends to constrain profits, as such companies are obligated to periodically pay off their liabilities and the related expenses. Thus, the higher the liabilities, the lower the profits are.

In terms of financial leverage, Table 5 shows that the results are similar to those for the capital structure ratio $\left(C A P_{t}\right)$, as the relationship between profitability $\left(B E P_{t}\right)$ and the financial leverage ratio $\left(F I N_{t}\right)$ is statistically insignificant for all sample countries. Nonetheless, a negative and significant relationship is found for large-sized companies in the Philippines and small-sized companies in Singapore.

With regard to the relationship between profitability $\left(B E P_{t}\right)$ and liquidity $\left(L I Q_{t}\right)$, a positive and significant relationship is found in the case of Malaysia, as shown in Table 4, particularly for large-sized and medium-sized Malaysian companies (as shown in Table 5). This positive result, which is consistent with the studies of Goddard et al. (2005) and Deloof (2003), indicates that the ability of financially strong listed companies to cover outstanding short-term obligations contributes to increased profits. Nonetheless, for the other sample countries, a significant relationship between profitability $\left(B E P_{t}\right)$ and liquidity $\left(L I Q_{t}\right)$ is not found. 
Table 5. Dynamic regression analysis of sub-sample data: Profit-growth relationship Dependent Variable: Profit $\left(\boldsymbol{B E P}_{t}\right)$

\begin{tabular}{|c|c|c|c|c|c|c|}
\hline \multicolumn{7}{|c|}{ Panel A: Malaysia and Philippines } \\
\hline \multirow{2}{*}{$\begin{array}{l}\text { Independent } \\
\text { Variables }\end{array}$} & \multicolumn{3}{|c|}{ Malaysia } & \multicolumn{3}{|c|}{ Philippines } \\
\hline & Large & Medium & Small & Large & Medium & Small \\
\hline \multirow{2}{*}{$\boldsymbol{B E P}(t-1)$} & 0.085 & 0.053 & 0.162 & $-0.250^{* * *}$ & $-0.10^{* * *}$ & $-0.012^{* * *}$ \\
\hline & 1.474 & 1.040 & 1.630 & -6.759 & -2.725 & -3.103 \\
\hline \multirow[b]{2}{*}{$\Delta$ Size $_{(t-1)}$} & -0.0000 & -0.0000 & 0.0000 & $-0.0000^{* *}$ & $-0.0000^{*}$ & 0.0000 \\
\hline & -1.134 & -1.078 & 0.832 & -1.970 & -1.934 & 0.782 \\
\hline \multirow{2}{*}{$\boldsymbol{C A P}_{(t)}$} & 0.001 & 0.008 & 0.003 & $-0.001^{*}$ & 0.0000 & 0.003 \\
\hline & 1.427 & 1.512 & 0.409 & -1.942 & 0.429 & 0.713 \\
\hline \multirow{2}{*}{$\boldsymbol{F I N}_{(t)}$} & -0.001 & -0.011 & -0.004 & $-0.002^{* *}$ & -0.0002 & -0.012 \\
\hline & -0.879 & -1.728 & -0.403 & -2.109 & -0.511 & -0.756 \\
\hline \multirow{2}{*}{$L I Q_{(t)}$} & $0.0001^{* *}$ & $0.001^{*}$ & 0.004 & 0.0001 & 0.004 & -0.011 \\
\hline & 2.238 & 1.862 & 1.631 & 0.210 & 1.276 & -0.943 \\
\hline
\end{tabular}

\begin{tabular}{|c|c|c|c|c|c|c|}
\hline \multicolumn{7}{|c|}{ Panel B: Singapore and Thailand } \\
\hline \multirow{2}{*}{$\begin{array}{l}\text { Independent } \\
\text { Variables }\end{array}$} & \multicolumn{3}{|c|}{ Singapore } & \multicolumn{3}{|c|}{ Thailand } \\
\hline & Large & Medium & Small & Large & Medium & Small \\
\hline \multirow{2}{*}{$\boldsymbol{B E P}(t-1)$} & $-1.357^{*}$ & $-0.53^{* *}$ & $-0.14^{* * *}$ & $-0.105^{* * *}$ & $-0.35^{* * *}$ & $-0.068^{*}$ \\
\hline & -1.844 & -2.257 & -4.461 & -150.072 & -6.115 & -1.716 \\
\hline \multirow{2}{*}{$\Delta$ Size $_{(t-1)}$} & 0.0000 & -0.0000 & 0.0000 & -0.0000 & -0.0000 & 0.0000 \\
\hline & 0.554 & -0.741 & 0.516 & -0.484 & -0.170 & 1.036 \\
\hline \multirow{2}{*}{$\boldsymbol{C A P}_{(t)}$} & -0.063 & 0.001 & $-0.019^{* *}$ & -0.151 & -0.0001 & -0.0000 \\
\hline & -0.072 & 1.113 & -2.224 & -0.832 & -0.179 & -0.325 \\
\hline \multirow{2}{*}{$\operatorname{FIN}_{(t)}$} & -0.948 & -0.002 & $-0.026^{* *}$ & 0.180 & 0.0001 & 0.0003 \\
\hline & -1.715 & -1.131 & $-2.006^{* *}$ & 0.836 & 0.282 & 0.327 \\
\hline \multirow{2}{*}{$L I Q_{(t)}$} & -0.056 & 0.003 & 0.013 & 1.052 & -0.000 & 0.0003 \\
\hline & -0.590 & 1.523 & 1.647 & 0.790 & -0.128 & 0.496 \\
\hline
\end{tabular}

Notes: The number in the first line is the regression coefficient, while the number in the second line is its related p-value. $*$, **, and $* * *$ denote significance at the $10 \%, 5 \%$, and $1 \%$ levels, respectively.

\section{CONCLUSION}

This study investigates the dynamic linkages between companies' growth and profitability, following Goddard et al. (2004) and Nakano and Kim (2011). This study also examines whether Gibrat's Law, which states that companies' growth rate is independent of their size, exists. This study also explores whether the persistence of profitability is observed in ASEAN countries. Using a sample of listed companies in the ASEAN-4 countries for the period from 1972 to 2014 and the GMM method suggested by Arellano and Bond (1991), the empirical analysis finds that companies' growth is not independent of their size. Smaller companies are more likely to grow 
faster than larger companies. Because of this finding, we can conclude that Gibrat's Law fails to hold in the cases of Malaysia, the Philippines, Singapore, and Thailand.

Additionally, the results show that the persistence of growth, in which past growth positively affects current growth, does not exist. Although the study finds a significant relationship, the empirical results show an inverse relationship in some sectors of Malaysia, Singapore and Thailand, which suggests a slowing growth potential in these countries. The result of a negative relationship is not surprising. It suggests that Malaysia, Singapore, and Thailand are small countries in terms of market size with growth rates that are relatively stable. For small countries, therefore, a negative relationship is expected. Large countries such as the U.S., India or even China have more potential to grow faster, and therefore a positive relationship is more likely to be found in such countries.

Moreover, the results of this study reveal that past profits appear to be positively related to companies' growth, thus confirming the findings of Goddard et al. (2004) and Nakano and Kim (2011). However, companies' growth is not the determinant of profitability for all the sample countries, although profitability is the determinant of companies' growth. Finally, the results suggest that profits are not persistent, as past profits negatively affect current profits.

Nonetheless, the results from the four ASEAN countries vary by country. Understanding the unique characteristics of each country can allow global managers, investors and practitioners to manage their portfolios, investments and related risks more effectively.

This study is not without limitations. As the study emphasized the use of countries' GDP for the purposes of clustering, the results represent the effects of size, growth and profitability on a country's competitiveness. However, the effects of industry structures operating across borders may provide insightful results regarding companies within different industries. Thus, further research may extend this study by clustering companies with similar industry structures across countries, regardless of their country of residence, and testing them together by using industry structure as a grouping factor. Moreover, further research can expand the scope to incorporate countries' related factors, such as foreign trade, and economic factors that might influence the growth and profitability of companies.

\section{REFERENCES}

Arellano, M., \& Bond, S. (1991). Some tests of specification for panel data: Monte Carlo evidence and an application to employment equations. Review of Economic Studies, 58(2), 277-297. https://doi.org/10.2307/2297968 
Audretsch, D. B., Santarelli, E., \& Vivarelli, M. (1999). Start-up size and industrial dynamics: Some evidence from Italian manufacturing. International Journal of Industrial Organization, 17(7), 965-983. https://doi.org/10.1016/S0167-7187(98)00002-2

Coad, A. (2007). Testing the principle of 'growth of the fitter': The relationship between profits and company growth. Structural Change and Economic Dynamics, 18(3), 370-386. https://doi.org/10.1016/j.strueco.2007.05.001

Coad, A. (2010). Exploring the processes of company growth: Evidence from a vector auto-regression. Industrial and Corporate Change, 19(6),1677-1703. https://doi.org/10.1093/icc/dtq018

Coad, A., Rao, R., \& Tamagni, F. (2011). Growth processes of Italian manufacturing companies. Structural Change and Economic Dynamics, 22(1), 54-70. https://doi.org/10.1016/j.strueco.2010.09.001

Cowling, M. (2004). The growth-profit nexus. Small Business Economics, 22(1), 1-9. https://doi.org/10.1023/b:sbej.0000011568.42714.c9

Deloof, M. (2003). Does working capital management affect profitability of Belgian firms? Journal of Business Finance \& Accounting, 30 (3-4), 573-588. https://doi.org/10.1111/1468-5957.00008

Distante, R., Petrella, I., \& Santoro, E. (2018). Gibrat's law and quantile regressions: An application to firm growth. Economics Letters, 164, 5-9. https://doi.org/10.1016/j.econlet.2017.12.028

Dunne, P., \& Hughes, A. (1994). Age, size, growth and survival: UK companies in the late 1980's. Journal of Industrial Economics, 42(2), 115-140. https://doi.org/10.2307/2950485

Evans, D. S. (1987). The relationship between company growth, size, and age: Estimates for 100 manufacturing industries. Journal of Industrial Economics, 35(4), 567-581. https://doi.org/10.2307/2098588

Gao, B., Chan, W.K., Chi, L., \& Deng, X. (2016). Size and growth dynamics of online stores: A case of China's Taobao.com. Electronic Commerce Research and Applications, 17,161-172. https://doi.org/10.1016/j.elerap.2016.04.005

Geroski, P.A., Lazarova, S., Urga, G., \& Walters, C.F. (2003). Are differences in company size transitory or permanent? Journal of Applied Econometrics, 18(1),47-59. https://doi.org/10.1002/jae.676

Geroski, P. A., Machin, S. J., \& Walters, C. F. (1997). Corporate growth and profitability. The Journal of Industrial Economics, 45(2), 171-189.

https://doi.org/10.1111/1467-6451.00042

Gibrat, R., (1931). Les inegalite economiques. Paris: Sirey.

Goddard, J., Molyneux, P., \& Wilson, J. (2004). Dynamics of growth and profitability in banking. Journal of Money, Credit and Banking, 36(6), 1069-1090. 
https://doi.org/10.1353/mcb.2005.0015

Goddard, J., Tavakoli, M., \& Wilson, J. (2005). Determinants of profitability in European manufacturing and services: Evidence from a dynamic panel data. Applied Financial Economics, 15(18),1269-1282.

https://doi.org/10.1080/09603100500387139

Goddard, J., Wilson, J., \& Blandon, P. (2002). Panel tests of Gibrat's Law for Japanese manufacturing. International Journal of Industrial Organization, 20(3), 415-433. https://doi.org/10.1016/s0167-7187(00)00085-0

Gupta, M. C. (1969). The effect of size, growth, and industry on the financial structure of manufacturing companies. The Journal of Finance, 24(3),517-529. https://doi.org/10.1111/j.1540-6261.1969.tb00370.x

Gupta, M. C. (1981). Minimum efficient scale as a determinant of concentration: A reappraisal. Manchester School, 49(2), 153-164. https://doi.org/10.1111/j.1467-9957.1981.tb00943.x

Hart, P.E., \& Oulton, N. (1996). Growth and size of firms. The Economic Journal, 106(438), 1242-1252.

Lee, S. (2014). The relationship between growth and profit: Evidence from companylevel panel data. Structural Change and Economic Dynamics, 28, 1-11. https://doi.org/10.1016/j.strueco.2013.08.002

Liñares-Zegarra, J., \& Wilson, J.O.S. (2018). The size and growth of microfinance institutions. The British Accounting Review, 50(2),199-213. https://doi.org/10.1016/j.bar.2017.11.006

Markman, G. D., \& Gartner, W. B. (2002). Is extraordinary growth profitable? A study of Inc. 500 high-growth Companies. Entrepreneurship Theory and Practice, 27(1), 65-75. https://doi.org/10.1111/1540-8520.271004

Mueller, D. C. (1977). The persistence of profits above the norm. Economica, 44(176), 369-380. https://doi.org/10.2307/2553570

Myers, S.C., \& Majluf, N. S. (1984). Corporate financing and investment decisions when firms have information that investors do not have. Journal of Financial Economics, 13(2), 187-221. https://doi.org/10.1016/0304-405x(84)90023-0

Nakano, A., \& Kim, D. (2011). Dynamics of growth and profitability: The case of Japanese manufacturing companies. Global Economic Review, 40(1),67-81. https://doi.org/10.1080/1226508x.2011.559329

Nunes, P. M., \& Serrasqueiro, Z. (2015). Profitability determinants of Portuguese knowledge-intensive business services: Empirical evidence using panel data models. Applied Economic Letter, 22(1),51-56. https://doi.org/10.1080/13504851.2014.925041 
Nunes, P. M., Serrasqueiroa, Z. M., \& Sequeira, T. N. (2009). Profitability in Portuguese service industries: A panel data approach. The Service Industries Journal, 29(5), 693-707. https://doi.org/10.1080/02642060902720188

Oliveira, B., \& Fortunato, A. (2006). Testing Gibrat's law: Empirical evidence from a panel of Portuguese manufacturing companies. International Journal of the Economics and Business, 13(1), 65-81. https://doi.org/10.1080/13571510500519996

Shehzad, C. T., De Haan, J., \& Scholtens, B. (2013). The relationship between size, growth and profitability of commercial banks. Applied Economics, 45(13), 17511765. https://doi.org/10.1080/00036846.2011.637896

Struyf, A., Hubert, M., \& Rousseeuw, P.J. (1997). Clustering in an object-oriented environment. Journal of Statistical Software, 1(4), 1-30.

https://doi.org/10.18637/jss.v001.i04

Phassawan Suntraruk holds a $\mathrm{PhD}$ and is an Assistant Professor of Accounting in the Business Administration Division, Mahidol University International College, Nakhonpathom, Thailand. Her areas of interest include management accounting, firm performance, corporate governance, investment strategy, asset pricing, and corporate finance.

Kanix Bukkavesa (Corresponding author) holds a $\mathrm{PhD}$ and a CFA and is a Senior Lecturer of Finance in the Business Administration Division, Mahidol University International College, Nakhonpathom, Thailand. Her areas of interest include corporate finance, fundamental investment analysis, technical analysis and quantitative investment analysis, corporate governance and behavioral finance, portfolio and investment strategy, and asset pricing.

Nat Kulvanich holds a PhD and is a Lecturer in Department of Statistics, Faculty of Commerce and Accountancy, Chulalongkorn University, Bangkok, Thailand. His areas of interest include panel data analysis, point process, time-series analysis, and categorical data analysis. 